\title{
Brexit: A Fluke or the Future of British Conservatism? Analyzing the Post-Brexit Conservative Party's Populist Status Quo
}

\author{
Jacob Winn, George Washington University
}

\begin{abstract}
The Brexit vote-the British people's vote to leave the European Union in 2016-represents the outcome of a successful populist movement. ${ }^{1}$ More recently, the Conservative Party's staggering 2019 electoral success demonstrated that the populist "Get Brexit Done" message remains popular among both traditional Conservatives and broad swaths of the working class in former Labour Party strongholds. This study aims to explain the Conservative Party's marked change in rhetoric and policy, as well as factional shifts within the halls of Westminster, in response to the ongoing Brexit negotiations. While some scholars look at the supply-side causes of populism (elites and political parties) and others look at the demand-side causes (the voters), this study applies a third school of thought that examines the relationship between supply and demand by analyzing a series of interviews with Conservative Party staff as well as public opinion polling. In doing so, the study concludes that there has

[1] Jacob Winn is a Fall 2020 graduate from George Washington University's Elliott School of International Affairs. He earned a Bachelor of Arts degree in International Affairs, with a concentration in International Politics, and a double major in Political Science. At GW, he was a member of the Dean's Scholars Program, through which he produced his research on Brexit, and was inducted as a member of Phi Beta Kappa and Pi Sigma Alpha. Jacob's research on the influence of the Brexit movement on the British Conservative Party has been presented at a number of conferences and symposia, including the Dean's Scholars Symposium, the 2021 National Conference on Undergraduate Research, and at the University of Pittsburgh's European and Eurasian Undergraduate Research Symposium. He is deeply interested in domestic and international politics, policy, and research. Jacob can be contacted at: jacob-winn@comcast.net.
\end{abstract}


been a deep, reciprocal, and simultaneous onset of populist Euroscepticism within both the Conservative Party and the working class that has structurally re-aligned the Conservative Party for decades to come, from more 'libertarian' to more 'authoritarian' in nature. A feedback loop between the new Conservative base and the Conservative Party has rendered and reciprocated a new mentality among voters. This research contributes to the existing literature as an example of the aftermath of populist movements when both elites and voters are able to forge cooperative relationships to achieve their goals.

\section{Introduction}

Since the 2007-2008 global financial crisis and the Great Recession, nations have persevered by undertaking the difficult process of economic recovery together. The European Union and its member states, through unprecedented unity and communication, created stimulus packages and financial reforms that have since lowered unemployment levels, raised GDP per capita, and reinvigorated European businesses and the financial sector. ${ }^{2}$ However, despite these recent gains, this topline analysis does not account for the significant portion of EU citizens who have lost faith in the European unity project that the economic downturn fueled. ${ }^{3}$ The strict austerity measures imposed upon European governments were perceived as demeaning and counterproductive to those out of work. Meanwhile, increased immigration from the Middle East and North Africa culminated in the Syrian refugee crisis of 2015 and provoked a wave of nativism. ${ }^{4}$ Rising economic anxiety, increasing nationalist sentiments, and Euroscepticism granted savvy populist movements across the continent newfound electoral success in the

[2] "Eurostat Economic Indicators," report, Eurostat, European Union, https://ec.europa.eu/eurostat/cache/infographs/economy/desktop/index.html.

[3] Jean-Claude Juncker, "President Juncker Delivers State of the Union Address 2017," European Commission, September 13, 2017, https://ec.europa.eu/commission/ presscorner/detail/en/SPEECH_17_3165; Alina Polyakova and Anton Shekhovtsov, "On The Rise: Europe's Fringe Right," World Affairs 179.1 (2016): 70-80, https://doi. org/10.1177/0043820016662746

[4] Ibid., 71 .
2014 European Parliament elections. ${ }^{5}$ In the same year, representatives of far-right parties, who had not seen significant electoral success since their modern debuts in the 1980 s, began entering national parliaments and governments at significantly higher rates. ${ }^{6}$ In the United Kingdom, such a movement resulted in the Brexit movement, the successful Leave Campaign, and the country's formal exit from the European Union on December 31st, 2020.

Since the end of World War II, European governments have erected the European Union and implemented increasingly outward-facing foreign policies to foster a cohesive European identity, economic interdependence, and a common supranational policy outlook. Modern European populist movements represent the most pressing challenge to the prevailing system of liberal democracy to date, one which will determine the direction of Europe for decades. The movement's success or failure will define Europe's future policy positions in immigration, the treatment of minorities, and the continued growth of the European Union project. As such, the issue at hand warrants significant scholarly study. Contemporary populist parties appeal to a narrative of "the people" against "European elites," and a need for a "national renaissance" in which domestic policies, and national traditions, reassert themselves over those of Brussels. ${ }^{7}$ As such, the brand of European populism that is successful today is partly nationalist and quite Eurosceptic. In response to the current populist wave that has emerged on the political right today, mainstream conservative parties have shifted their policies and rhetoric further towards the far-right to share in this electoral success. ${ }^{8}$

[5] Daphne Halikiopoulou and Sofia Vasilopoulou, "Support for the Far Right in the 2014 European Parliament Elections: A Comparative Perspective," The Political Quarterly 85.3 (2014): 285-88, https://doi.org/10.1111/1467-923x.12102

[6] Matt Golder, "Far Right Parties in Europe," Annual Review of Political Science 19.1 (2016): 477-97, https://doi.org/10.1146/annurev-polisci-042814-012441

[7] Yascha Mounk, "Pitchfork Politics: The Populist Threat to Liberal Democracy," Foreign Affairs 93.5 (2014): 29-31, https://www.jstor.org/stable/24483300

[8] Slawomir Sierakowski. "In Europe, the Only Choice Is Right or Far-Right," Foreign Policy Magazine, May 21, 2018, https://foreignpolicy.com/2018/05/21/in-europe-the-only-choice-is-right-or-far-right/ 
Across Europe, the post-industrial transition of manufacturing economies to service economies has threatened the traditional industrial base of working-class laborers and their traditional ways of life. This is especially true in Northern England, a formerly vibrant industrial manufacturing hub that currently faces job scarcity and stagnant incomes as a result of the channeling of wealth toward major cities at the cost of traditional, rural ways of life. ${ }^{9}$ While left-wing political parties such as the British Labour Party had traditionally received high electoral support from working class demographics, their demand-side interests remained unfulfilled and disillusioned voters have begun to turn elsewhere, to far-right parties like the UK Independence Party (UKIP). The resulting wave of populism, nationalism, and anti-institutionalism has manifested as Euroscepticism. To address this topic, I analyzed Brexit, the British case of withdrawal from the United Kingdom, and its impact on the political party that supported it-the Conservative Party.

This modern far-right populism found its footing quite recently and has grown at an explosive rate. Additionally, due to the recency of the Brexit vote and the ongoing nature of the post-Brexit years, scholarship has not fully explored the evolution of this case. Analysis of European populist political parties has not fully accounted for Europe's present-day supranationalism and interdependence. The literature on modern European populism and nationalism discusses supply-side ${ }^{10}$ and demand-side ${ }^{11}$ factors contributing to the promotion and adoption of populism, with an emerging scholarly consensus that demand-side factors are more impactful. ${ }^{12}$ However, this consensus ought to be, and has already been,

[9] Italo Colantone and Piero Stanig, "The Surge of Economic Nationalism in Western Europe," Journal of Economic Perspectives 33.4 (2019): 128-51, https://doi.org/10.1257/ jep.33.4.128

[10] According to Halikiopoulou et al., supply-side factors are "the ways in which parties use nationalism strategically in an attempt to broaden their appeal by presenting themselves as legitimate to large sections of the population."

[11] According to Halikiopoulou et al., demand-side factors are the grievances and social cleavages that create demand for far-right parties.

[12] Daphne Halikiopoulou and Tim Vlandas, "What Is New and What Is Nationalist about Europe's New Nationalism? Explaining the Rise of the Far Right in Europe," Nations and Nationalism 25.2 (2019): 409-34, https://doi.org/10.1111/nana.12515 questioned: a focus on just the supply-side or the demand-side does not account for the "inherent interaction between supply and demand" that determines far-right parties' electoral and political success. ${ }^{13}$ As a result, scholars have begun to develop a new school of thought, which I call the "Third Way" school of thought. Using the "Third Way" framework, scholars seek to examine the relationship between supply and demand in order to investigate not just populism's antecedents, but also how those antecedents play out in the dynamics of populism. This paper applies the "Third Way" framework to the Brexit case, exploring the way that the British Conservative Party has been impacted by the populism that it has both supplied to the public and absorbed from public demands.

So why has the Conservative Party changed so markedly in the years following the Brexit referendum, and what explains the Party's rhetorical and general policy changes as well as its factional shifts? Through interviews with affiliates of the Conservative Party, I find evidence of a set of conditions that came together in a perfect storm for a political realignment of their Party: emergent populism within the Conservative Party apparatus, and a newfound expanded voter base that has come to include more of the English working class in the conflict-ridden post-Brexit years. Since the onset of the Brexit referendum campaigns, a political and electoral realignment has been propelled by a feedback loop of ideas between the Party, which co-opted populist rhetoric from the UK Independence Party and its newly expanded base, which demanded small-c conservative, non-elite candidates that could "Get Brexit Done" and counter London-centric politics. As such, the composition of the British center-right has fundamentally shifted. Furthermore, with the support of an expanded majority that demands that the Party reject elite politics, the newly-elected Members of Parliament and the Conservative Party's current leadership are upending the party's long-standing libertarian tradition by embracing stricter immigration and tough-oncrime law enforcement policies, while governing with a mandate from voters who demand paternalistic and "Britain-first" economic reforms.

[13] Golder, "Far Right Parties in Europe," 490. 


\section{The United Kingdom Today: From Early Euroscepticism to Boris Johnson}

Populism is especially pervasive in the United Kingdom, where the victory of the Leave campaign in the Brexit referendum (known officially as the "United Kingdom European Union membership referendum") has upset British politics. According to one of this study's interviewees, the Brexit movement contains many nationalist elements that appealed to British voters who are "naturally small-c conservative," but who may not have historically voted for the Conservative Party, and those who prefer a strong military, no overreach of external forces, and controlled immigration. ${ }^{14}$ This is not unique to the UK, nor the British Conservative Party-the ability of a movement to alter a state's politics on this scale using similar rhetoric, politics, and policy is absolutely possible and demonstrably occurring across the world. ${ }^{15}$ However, the Brexit movement is an especially salient example of far-right populism because of its success: the Brexit referendum occurred and triggered the United Kingdom's exit from the European Union. As this paper will discuss, the Conservative Party's response to far-right populism has been to embrace Euroscepticism in Parliamentary affairs. Under Prime Minister Boris Johnson's leadership, the Party has signaled that it plans to prioritize national interests and return the United Kingdom to the period of lost glory in the decades immediately following World War II, a time prior to the country's "mistaken experiment" with supranationalism. As such, this case demonstrates a broad shift in the supply- and demand-side factors of nationalism, the way in which populism has affected British politics; is more consequential than in any other country in Europe today. The underlying Eurosceptic sentiments, anti-immigrant attitudes, and economic woes that propelled the Leave campaign have not subsided. Rather, they have become a dominant wing of the mainstream Conservative Party. David Cameron's promise to reform Britain's relationship

[14] According to interviewees, a "small-c conservative" refers to someone who adheres to a conservative political ideology. This is distinct from a "Conservative." someone who is a member, politician, or dedicated voter of the British Conservative Party.

[15] See the cases of the Republican Party in the United States, the Canadian Conservative Party, Italian Five Star Movement. with the EU, regardless of the outcome of the referendum, marked his party's shift towards a mainstream pro-Brexit position. ${ }^{16}$ That said, Britain's Euroscepticism had emerged long before Cameron's premiership.

British Euroscepticism has had a place in both the Labour and Conservative Parties since the 1970s, during which the United Kingdom joined the European Community (EC). The Labour Party was initially the more Eurosceptic of the two; its leadership and membership alike saw the European Communities as increasingly neoliberal and unable to address working class challenges. ${ }^{17}$ In 1975 , future Labour leader Jeremy Corbyn voted with the majority of the Labour Party in its bid to challenge the processes of European integration. His own Euroscepticism persisted throughout his role as party leader up to the 2016 Brexit referendum campaign. ${ }^{18}$ For its part, the Conservative Party had its own Eurosceptic elements. Though she supported the European project for much of her career, Margaret Thatcher eventually became wary of European integration. ${ }^{19}$ In her 1988 Bruges speech, she warned against forming a "European super-state," and in 1990 she proclaimed "no, no, no" in the House of Commons regarding the creation of the European Union. ${ }^{20}$ In the wake of the 1992 Maastricht Treaty-the founding treaty of the European Union-the Conservative Party formed organizations such as the European Research Group, which sought to provide an intellectual and ideological critique of the European Project. At the same time,

[16] Tim Oliver, "Goodbye Britannia? The International Implications Of Britain's Vote To Leave The EU," Geopolitics, History, and International Relations 8.2 (2016): 214-15, https://doi.org/10.22381/GHIR82201610

[17] Nicholas Startin, "Have We Reached a Tipping Point? The Mainstreaming of Euroscepticism in the UK," International Political Science Review / Revue Internationale de Science Politique 36.3 (2015): 313, https://doi.org/10.1177/0192512115574126

[18] "How Long Can Labour's Eurosceptic Leader Keep Europhile Members Happy?" The Economist, January 10, 2019. https://www.economist.com/britain/2019/01/10/ how-long-can-labours-eurosceptic-leader-keep-europhile-members-happy

[19] "Thatcher and Her Tussles with Europe," BBC News, April 8, 2013, https://www. bbc.com/news/uk-politics-11598879

[20] Margaret Thatcher, "Speech to the College of Europe ('The Bruges Speech')," September 20, 1988; "Euro Moments: Thatcher Says 'No, No, No' to Europe," BBC News, May 14, 2014, https://www.bbc.com/news/av/uk-politics-27053536 
the UK Independence Party (UKIP) emerged as a leading advocate for Britain's exit from the European Union. It was slow to gain traction, but eventually found electoral success in the European Parliament due to the parliamentary use of proportional representation and the far-right populist rhetoric of its leader, Nigel Farage. After the onset of the Great Recession and the Labour Party's signing of the Lisbon Treaty, UKIP amassed right-wing support under Farage in the 2009 European Parliamentary elections, raising Conservative Party concerns that UKIP might siphon off voters in future national elections. ${ }^{21}$

Since these first instances of Euroscepticism, the U.K. has mirrored other twenty-first century powers in converting to a largely urban, service-based economy-especially centered in London. ${ }^{22}$ On the other hand, the manufacturing economies of English Midlands, the North of England, and Wales have been left struggling behind the rest of the country. ${ }^{23}$ As such, it is no coincidence that populists were able to unite far-right nationalist voices, right-wing Conservative voices, and populist/far-left Labour voices into a coalition against globalization and the perceived 'others' integrating from other EU countries. As the populist Eurosceptic movement lost the support of the Labour Party prior to the Brexit referendum, it turned its attention entirely towards the right. ${ }^{24}$ Many savvy politicians who represented the Conservative Party, both locally and nationally, noticed how this turn resonated with rural voters from across the political spectrum. Ideals such as providing for one's own poor (rather than relying on the European Development Fund), "writing one's own laws," and "controlling one's own borders" pervaded the discourse of both the Conservative Party's voter base and its Party Parliamentary Group in greater numbers, and in a louder volume, than before. Since the referendum, the underlying trends of populism have continued to sweep through the Conservative Party and its voters.

[21] Roland Flamini, “The UK Independence Party: Euroskeptics Rattle Cameron," World Affairs 176.2 (2013): 37, https://www.jstor.org/stable/43554778

[22] “The Great Divide," The Economist, September 15, 2012, https://www.economist. com/britain/2012/09/15/the-great-divide

[23] Ibid.

[24] Flamini, “The UK Independence Party: Euroskeptics Rattle Cameron,” 37-38.
On December 12th, 2019, Prime Minister Boris Johnson's Conservative Party won its largest government majority since the 1980 s as a result of former Labour voters abandoning the Labour Party in its traditional stronghold districts, such as in the English Midlands. On February 1st, 2020, the United Kingdom formally withdrew from the European Union, entering a transition period for the UK and EU to arrange departure agreements before the withdrawal took effect on January 1st, 2021.

\section{Literature Review}

The resurgence of the modern European far-right populist movement over the last decade has generated a new scholarship on the topic, but many questions remain regarding how these political movements interact with their respective voter bases and affect mainstream political parties and politics at-large. To analyze this issue, scholars tend to divide populism and nationalism on two fronts. First, scholars in what this paper refers to as the "Demand Influences Supply" (DIS) school of thought study the demand-side factors of far-right nationalism: how voters overtly demand populism from their elected officials in response to real or perceived economic or social grievances. ${ }^{25}$ Second, scholars in the what this paper refers to as the "Supply Influences Demand" (SID) school of thought focus on the supply-side factors, which are "the ways in which parties use [populism and/or nationalism] strategically in an attempt to broaden their appeal by presenting themselves as legitimate to large sections of the population." ${ }^{26}$ Scholars within each of these schools of thought consider how their respective side drives the other, as well as how supply-side and demand-side factors function in isolation. However, the interaction between the two different factors has been under-studied. ${ }^{27}$ In recent years, some have proposed what I term a "Third Way" approach. Scholars from this school of thought contend that there is a two-way interaction between supply- and demand-side

[25] Halikiopoulou and Vlandas, "What Is New and What Is Nationalist about Europe's New Nationalism?" 411.

[26] Halikiopoulou and Vasilopoulou, "Support for the Far Right in the 2014 European Parliament Elections: A Comparative Perspective," 286.

[27] Golder, "Far Right Parties in Europe, " 490. 
factors. ${ }^{28}$ Crucially, they also assert that supply-side and demand-side factors must both be maximized to facilitate populist party success; neither is seen as inherently more important than the other. This literature review examines the "Demand Influences Supply" and "Supply Influences Demand" schools, then proceeds to discuss the new "Third Way" school of thought.

\section{The "Demand Influences Supply" Approach}

Scholars in the "Demand Influences Supply" school consider demand-side characteristics to be the drivers of the present rise in European far-right nationalist parties and consider supplied nationalism to be a secondary response. This historically dominant school of thought dates back to Scheuch and Klingemann's 1967 treatise, which outlines the "normal pathology thesis" of the far-right. ${ }^{29}$ The theory asserts that farright values are at odds with liberal democracy, but that there is always a risk of a far-right party rising in all democracies. Scheuch and Klingemann argue that far-right parties spread through situational demands by the public. ${ }^{\circ 0}$ Typically, scholars study one of three key demand-side grievances-economic insecurity, cultural change, and reduced trust in elites-that lend themselves to populist party success.

The first approach examines the economic threats that lead to popular grievances and populist action. Globalization and the Great Recession have contributed to economic insecurity in many Western democracies as a result of the offshoring of jobs and automation of low-skill labor, which both contract wages. This labor market precarity manifests for workers as "a deep personal conflict at the interface of sociopolitical context and individual identity. ${ }^{{ }^{11}}$ As Post asserts in his extreme lead-

[28] Cas Mudde, "The Populist Radical Right: A Pathological Normalcy," West European Politics 33.6 (2010): 1177, https://doi.org/10.1080/01402382.2010.508901

[29] Erwin K. Scheuch and Hans D. Klingemann, "Theorie des Rechtsradikalismus in westlichen Industriegesellschaften," Hamburger Jahrbuch für Wirtschafts und Gesellschaftspolitik, 12 (1967): 11-29. Cited in Mudde, "The Populist Radical Right: A Pathological Normalcy," 1170.

[30] Ibid.

[31] Karl Umbrasas, "Psychopolitics of the Current Nationalism," Journal of Strategic er-follower behavior framework, these individuals are the first to demand a strong leader to provide "an answer to a pervasive, and at the extreme, pathological feeling of ineffectiveness in life." ${ }^{22}$ Austerity measures imposed by the European Union were unpopular due to their cuts to social programs, and many voters thought that their nation's economic status was under threat. ${ }^{33}$ European nationalism is characterized by many voters who are nostalgic for their nation's 'better past,' and hope for national economic recovery. ${ }^{34}$ According to de Búrca, five economic factors are visible in both the British and American contexts: "(i) a reaction against immigration, (ii) concern about economic insecurity, (iii) a rejection of internationalism and transnationalism, (iv) a return to inward-looking (economic) nationalism and (v) a rise in authoritarian and illiberal sentiment." ${ }^{35}$

The second approach views populism through the lens of cultural change. In his identity crisis theory, Mounk observes that short-term fluctuations in the economy alone do not fully explain the rise of the farright. Rather, they must be accompanied by long-term cultural changes, ${ }^{36}$ such as the perceived 'threat' to national identity by immigrants and supranational organizations and the perceived decline in intergenerational living standards. ${ }^{37}$ European countries have undergone cultural integration after 1991, with the fall of the Soviet Union and the free movement of labor between European Union member states. They have

Security 10.4 (2017): 30, http://doi.org/10.5038/1944-0472.10.4.1616

[32] Jerrold Post, Leaders and Their Followers in a Dangerous World (Ithaca, NY: Cornell University Press, 2004), 195; Umbrasas, "Psychopolitics of the Current Nationalism," 31.

[33] Dani Rodrik, "Populism and the Economics of Globalization," Journal of International Business Policy, 2018, https://doi.org/10.1057/s42214-018-0001-4

[34] Hidde Bekhuis, Roza Meuleman, and Marcel Lubbers, "Globalization and Support for National Cultural Protectionism from a Cross-National Perspective," European Sociological Review 29.5 (2013): 1042, https://doi.org/10.1093/esr/jcs080

[35] Gráinne de Búrca, "How British Was the Brexit Vote?" in Brexit and Beyond: Rethinking the Futures of Europe, ed. Benjamin Martill and Uta Staiger (London, GBR: University College London Press, 2018): 47, https://doi.org/10.2307/j.ctt20krxf8.10

[36] Mounk, "Pitchfork Politics: The Populist Threat to Liberal Democracy", 29.

[37] Ibid., 30. 
also undergone cultural diversification since the 2015 influx of predominantly Muslim refugees..$^{38}$ Many workers who have seen their country's traditions and culture "change" wish to avoid this culture shock. Because establishment European political parties typically possess a pro-European Union orientation, discontented voters saw nationalism as the only viable alternative to express their Euroscepticism. ${ }^{39}$ Vasilopoulos et al. find that emotions resulting from cultural grievances play a role in demand for the far-right, ${ }^{40}$ as "angrier" voters are more likely to vote for far-right parties while more fearful voters are more likely to vote for mainstream parties. ${ }^{41}$

The final approach views popular trust in elites and institutions as instrumental for the rise of populism. In recent years, trust in elites has significantly diminished due to both economic and cultural upheaval. ${ }^{42}$ Mukand and Rodrik theorize cleavages between three separate societal groups: elites, the majority group, and the minority group $(s){ }^{43}$ Though cleavages between majority and minority groups can be based along any line of identity, including ethnicity and religion, cleavages between either of these groups and elites will always be visible on the basis of class. ${ }^{44}$ Moreover, voters will come to perceive the upper class as protectors of the status quo and extremist candidates as agitators of the status quo. ${ }^{45}$

[38] Polyakova and Shekhovtsov, "On the Rise: Europe's Fringe Right," 71.

[39] Hamid A. Ünver, "Corrective Parties and Conveyor Coalitions: Explaining the Rise of Third Parties in European Politics," Perceptions 21.2 (2016): 16, https://search. proquest.com/docview/1892979630/abstract/973196B434C6423BPQ/1

[40] See Pavlos Vasilopoulos et al., "Fear, Anger, and Voting for the Far Right: Evidence From the November 13, 2015 Paris Terror Attacks," Political Psychology 40.4 (2019): 679-

704, https://doi.org/10.1111/pops.12513

[41] Ibid., 686-690.

[42] Mudde, "The Populist Radical Right," 1167-1186.

[43] Sharun Mukand and Dani Rodrik, "The Political Economy of Liberal Democracy," CESifo Working Paper Series 6433 (2017): https://papers.ssrn.com/sol3/papers.cfm?abstract $\mathrm{id}=2973082$

[44] Ibid., 7.

[45] Leyla D. Karakas and Devashish Mitra, "Inequality, Redistribution and the Rise of Outsider Candidates," Games and Economic Behavior 124 (2020): 1-16, https://doi. org/10.1016/j.geb.2020.07.012

\section{The "Supply Influences Demand" Approach}

Another rapidly growing, though by no means new, set of scholars reject the classic consensus that voter demand is the primary driver of far-right populist success today. Instead, they argue that a generalized demand-side focus cannot explain inter- and intra-country variation in support for populist movements. They seek to explain why nationalism takes root in only a fraction of the locations where demand-side factors are present. Mudde argues that although demand-side factors do condition the success of far-right nationalist parties in Europe today, it is supply-side factors, such as party strength, party ideology, and party rhetoric, that truly determine whether or not these parties will be successful. ${ }^{46} \mathrm{He}$ asserts that far-right populist parties do not differ in function from other parties-they are the result of normal democratic operations that have "gone too far" and have created a political pathology. As such, Scheuch and Klingemann's "normal pathology thesis" ought to be known as the "pathological normalcy thesis."47 These scholars view far-right parties as "make or break" agenda-setters that influence voter demands, just like any other party.

"Supply Influences Demand" scholars also focus on party strength and ideology. Party strength is typically measured by analyzing media presence, legislative participation, and grassroots support. Mair notes that populist parties find the most success when voters perceive a degradation of the conception of 'the people' as the core component of democracy. He asserts that in response to this perceived degradation, far-right parties often leverage conceptions of the "lost nation" to gain voter support. ${ }^{4}{ }^{8}$ Furthermore, van Spanje finds that mainstream parties are less likely to ostracize a far-right party if it appears strong in just one or a few regional elections within a country. ${ }^{49} \mathrm{As}$ I will study in my

[46] Mudde, “The Populist Radical Right: A Pathological Normalcy," 1168.

[47] Ibid., 1178.

[48] Peter Mair, "Ruling the Void: The Hollowing of Western Democracy," New Left Review 42 (2006): 25-51, http://hdl.handle.net/1814/6418

[49] Joost van Spanje, "Parties Beyond the Pale: Why Some Political Parties Are Ostracized by Their Competitors While Others Are Not," Comparative European Politics 8.3 (September 2010): 354-83, http://dx.doi.org/10.1057/cep.2009.2 
case, scholars also identify party rhetoric as a crucial supply-side factor in determining the success of today's far-right. As such, they conduct content and discourse analyses and find historical or symbolic references within far-right politicians' speeches. As an extension of classic social exclusion theories, far-right nationalist parties today organize social exclusion based on nativist and xenophobic rhetoric pertaining to cultural differences rather than overt arguments of biological superiority. Mondon refers to this rhetoric as "neo-racism, cultural racism, or cultural differentialism" because it subtly implies to voters that European liberal democracy can only flourish in countries consisting of 'traditionally' European races. ${ }^{50}$ Polyakova and Shekhovtsov argue that today's far-right political parties have significantly toned down the rhetoric of overt biological racism and authoritarianism to avoid association with fascism. ${ }^{51}$ They demonstrate that today's most electorally successful far-right parties are ones that have been able to moderate their rhetoric to gain "electoral respectability" during election seasons..$^{52}$

\section{A "Third Way" Forward to Bridge the Gap?}

This literature review has delineated the sharp divide between the "Demand Influences Supply" and "Supply Influences Demand" schools. The driving direction of the supply-demand interaction remains a highly contested question in the literature on modern populism. However, limited research has begun to pursue a third path forward, which exists as a separate school of thought. As Golder argues in his study, this school of thought theorizes that supplied and demanded contemporary nationalism can only grow together, and will only produce far-right successes when both are maximized..$^{53}$ Lubbers and Scheepers have pioneered this practical model by quantitatively measuring the growth of demand-side factors together with ideological markers within France's

[50] Aurelien Mondon, "Populism, the 'People' and the Illusion of Democracy: The Front National and UKIP in a Comparative Context," French Politics 13.2 (June 2015): 144, http://dx.doi.org/10.1057/fp.2015.6

[51] Polyakova and Shekhovtsov, "On the Rise: Europe's Fringe Right," 73.

[52] Ibid.

[53] Golder, "Far Right Parties in Europe," 490.
National Rally party. ${ }^{54}$ Instead of focusing on the contentious direction of the party-voter interaction, they compare correlative analyses of the French electorate and National Rally ideological rhetoric to data from other Western European countries. ${ }^{55}$ Though promising, their comparative study and others like it have been regarded as incomplete because they overly condense different qualitative demand- and supply-side factors across many countries' scenarios into a framework of quantitative variables in a manner that does not wholly represent the social interactions within far-right nationalism..$^{6}$

Vines and Marsh also grapple with the need to move past supply- and demand- in isolation, instead arguing that we need to "move beyond explanations of the problem that [place] 'blame" on either the suppliers or demanders of populism..$^{57}$ They build on the concept of "anti-politics," which is political action and rhetoric that is perceived to be "outside" of a country's politics and that leads to developments such as "the decline in voting participation, party membership, and other forms of traditional political participation. ${ }^{.58}$ While Mete argues that anti-politics can be either passive (from below), with "activists questioning the existing political order," or active (from above), with "citizens being particularly attracted to populist leaders/parties," Vines and Marsh go a step further. ${ }^{59}$ Rather than acknowledging the possibility that both supply and demand can influence populist rhetoric in different cases, they assert that "anti-politics is a relational concept...[revolving] around the relationship between political authorities and citizens, which is interactive and iterative."60 Their proposition of interactive and iterative relation-

[54] Marcel Lubbers and Peer Scheepers, "French Front National Voting: A Micro and Macro Perspective," Ethnic and Racial Studies 25, no. 1 (January 1, 2002): 120-149, https://doi.org/10.1080/01419870120112085.

[55] Ibid., 137-140.

[56] Golder, "Far Right Parties in Europe," 490.

[57] Emma Vines and David Marsh, "Anti-Politics: Beyond Supply-Side versus Demand-Side Explanations," British Politics 13, no. 4 (December 1, 2018): 433-53, https:// doi.org/10.1057/s41293-017-0053-9.

[58] Ibid., 436

[59] Ibid.

[60] Vittorio Mete, "Four Types of Anti-Politics: Insights from the Italian Case," Mod- 
ality warrants greater analysis in order to understand the true relationship between the voters and politicians-a relationship that Vines and Marsh argue has become frayed and "decoupl[ed]," and is the real cause of anti-political populism. ${ }^{61}$ Given the deadlock in this body of academic literature, a unifying approach is needed to add to the scholarly understanding of how populism functions in Europe today. This research contributes to a more dynamic approach to the scholarly conversation by applying the "Third Way" school of thought and shedding light on how demand- and supply-side factors of populism interact in the British case.

\section{Methods}

My data collection and analysis employed an interpretivist epistemological approach. The nature and effects of populism in the British political system must be understood in its social context. The goal of my research has been to qualitatively explore sociopolitical interaction. My interpretivist approach has permitted me to communicate directly with British voters and political actors to understand their thoughts, opinions, and experiences. I allowed my interviewees to guide the conversation about what they saw as the most important aspects of the new Conservative Party and of the new British political landscape. To answer my research question within the British case, I observed the ways in which the ideology, rhetoric, and composition of the Conservative Party has changed since the Brexit referendum and onset of widespread British Euroscepticism. To do so, I organized and conducted semi-structured interviews with fifteen party actors within the Conservative Party, all from either England or Wales. These party actors included parliamentary assistants and office staffers, senior parliamentary staffers and communications officers, local Councilors, Young Conservative members, parliamentary office managers, and one Member of Parliament. ${ }^{62}$

ern Italy 15.1 (2010): 37-61, https://doi.org/10.1080/13532940903477872

[61] Vines and Marsh, "Anti-Politics: Beyond Supply-Side versus Demand-Side Explanations," 450.

[62] Of my 15 interviewees, 13 were Parliamentary staffers or assistants at various levels of seniority, 2 were local councilors, 2 were members of the Young Conservatives, and 1 was a MP. In total, 5 voted to remain, 9 voted to leave, and 1 did not disclose their vote.
These interviewees both steer change in the Conservative Party and are influenced by those changes. The views of party actors have not been deeply explored since the 2016 Brexit referendum, nor the landslide victory of the Conservative Party in the 2019 general election. I first asked questions related to their understanding of the history of populism, nationalism, and Euroscepticism in the UK, before turning to the history of the Brexit movement and post-referendum withdrawal. Next, I explored their perceptions pertaining to change within the Conservative Party. For example, I asked how or if they perceived the Party to have shifted across the Cameron, May, and Johnson premierships, and whether or not they perceived ideology or policy objectives to have changed in recent years. I also asked them to comment on any trends of continuity and change with respect to elite maneuvering, party rhetoric, and policy objectives from a supply perspective. Additionally, I sought to observe changes in voter demand by asking them about their perceptions as private citizens. Where relevant, I utilized my semi-structured format to follow up on common themes, such as the internal Conservative Party divide between 'libertarianism and 'authoritarianism, the role of immigration in the Brexit referendum, or their thoughts on the direction of the Conservative Party.

To garner the widest variety of perspectives available to me, I conducted Zoom interviews with as many people who were affiliated with the Conservative Party as possible. I reached out to Conservative Party offices, Parliamentary offices, Youth Conservative organizations, and local Councilor groups as possible interviewees. In addition to these interviews, I was also informed by a variety of public opinion data from the British Polling Council, which identifies how British politics have changed at historical points of transition throughout the twentieth century. I also consulted other twentieth century studies, news media, and all UK and EU parliamentary election results.

\section{Data Analysis Process}

I analyzed my data in accordance with the "Third Way" school, focusing on the interaction between supply-side and demand-side factors of nationalism. The purpose of my interviews with party actors was to bet- 
ter understand changes in the supply-side factors of nationalism, and to determine the demand-side factors of nationalism in the wake of the December 12th, 2019 parliamentary elections and the January 31st, 2020 exit from the European Union.

I conducted a thematic analysis of my fifteen interviews. First, each interview was recorded and transcribed for direct quotes. I also took copious notes on everything that each interviewee said. Then, all recurring pertinent statements and all statements that provided a novel viewpoint were sorted by theme. A view was considered pertinent and assigned a theme if it: (a) related to interactions between the Conservative Party and voters, (b) related to changes within either the Conservative Party or the public, (c) discussed a personal view that was not a broad reflection of public opinion, or (d) discussed or referenced populism and/ or nationalism (or referenced a sub-category of these ideas such as economic anxiety, globalization, or Euroscepticism). For a full list of coded themes and their frequency amongst all interviews, see Appendix B.

My analysis examined how voters remember the Brexit campaign, what it meant to them, and how their views of British politics and British political parties have shifted over time. Moreover, by asking party actors about changes in legislative affairs and strategy (as it relates to rhetoric and electoral politics), my analysis identified where party actors and voters converge and differ to ascertain the role populism played in each group's conceptualizations of, and interactions with, each other.

\section{Ethical Considerations and Limitations}

I reckoned with important ethical considerations while conducting my interviews. With respect to conducting interviews with Conservative Party actors, risk to participants may come in the form of job security considerations. For this reason, all data was anonymized and responses were obfuscated to ensure that responses would not indicate an interviewee's identity, specific career, or affiliation. A participant consent form discussed the inherent confidentiality risks posed by participating in interviews and provided a full overview of this study's purpose and scope. All interview recordings were stored offline using encryp- tion software-pending deletion and pursuant to the consent form. This study faced two limitations as a result of the COVID-19 pandemic. First, the virus made in-person interviews impossible. Conducting interviews virtually increased risks to confidentiality and could have theoretically precluded full honesty from participants despite precautions. Second, the pandemic also drastically (and understandably) increased the workload of all Conservative Party actors, from every Councilor to parliamentary staffer to Member of Parliament. As such, some sampled individuals declined to be interviewed due to other pressing priorities and lack of availability, which limited this study's interview pool.

\section{Findings and Discussion: The Core Issues of British Populism}

This section will describe several of the key themes occupying the Conservative Party and its voters before, during, and after the Brexit referendum. These key concerns were cited by interviewees as crucial to both the types of changes that have taken place within the Conservative Party, as well as the social mechanisms of action.

\section{Euroscepticism and Sovereignty}

The issue of sovereignty has been deeply rooted within the "vox pop"the "snippets of public opinion from people 'on the street'...of the British public," which raise "common concerns" such as "out of control immigration" and "tak[ing] back control of laws." ${ }^{33}$ Both of these concerns were discussed by interviewees, who saw the Brexit movement as primarily stemming from the United Kingdom's unique position off the coast of the mainland continent. Both Remainers and Leavers referred to the British people's long-standing reluctance towards the European Union and skepticism of bureaucracy. ${ }^{64}$ Euroscepticism, they said, had emerged in the Conservative Party during the Thatcher era. Those who

[63] Jonathan Hearn, "Vox Populi: Nationalism, Globalization And The Balance Of Power In The Making Of Brexit," in Brexit: Sociological Responses, ed. William Outhwaite (London, GBR: Anthem Press, 2017) 19, https://www.jstor.org/stable/j.cttlkft8cd.5 [64] "Remainer" interviewees were those who had disclosed that they had voted to 'Remain' in the European Union in the 2016 Brexit referendum; "Leaver" interviewees had voted to 'Leave'. 
wanted a less unified European Union, such as Bill Cash, made their ideas well-known to the public and to their party during the process of the ratification of the Treaty of Maastricht. Though they were able to negotiate decreased British contributions to the EU, many in the party infrastructure "privately wanted the European Union to remain a useful club and nothing more" and were not supportive of the European project. Most interviewees credited the large-scale shift in public sentiment to Tony Blair's signing of the 2009 Lisbon Treaty, which prompted UKIP's meteoric rise to third place in national polling. Most interviewees shared that UKIP's ability to push David Cameron's support of a referendum in 2015 was critical in instigating the Conservative Party's embrace of populism. Though Euroscepticism had begun to grow within the European Research Group since the 1993 Maastricht Treaty ratification, it was the Lisbon Treaty that increased its prevalence and increased concerns within the Conservative Party in Parliament's whips. Interviewees identified the signing of the treaty of Lisbon as the period in which the British government appeared to be "superseded" by Conservatives' outcry against the Labour Party and the solidified Eurosceptic sentiment.

Another issue that was crucial to changes in the Conservative Party was David Cameron's recession-era austerity policies, such as social service cutting, the imposition of tuition at universities, and business tax cuts, which signaled to the recently unemployed that Cameron was adhering to European Union policy rather than looking out for the British public. Nationalism had already surfaced from economic tensions related to globalism, offshoring, and migration, ${ }^{65}$ but "the degree to which individuals were adversely affected by the crisis and their discontent with the EU's handling of the crisis are major factors in explaining defection from mainstream pro-European to Eurosceptic parties in these elections." ${ }^{\prime 66}$ Some interviewees said that "Little Englanders" in the North

[65] Colantone and Stanig, "The Surge of Economic Nationalism in Western Europe," 129.

[66] Sara B. Hobolt and Catherine de Vries, "Turning against the Union? The Impact of the Crisis on the Eurosceptic Vote in the 2014 European Parliament Elections," Electoral Studies 44 (2016): 504, https://doi.org/10.1016/j.electstud.2016.05.006 were frustrated by the "London-centric and Brussels-centric narrative" that had advocated austerity, and the lack of democracy at the supranational level had left some feeling discounted and disdainful towards bureaucrats. Conservatives were shocked that UKIP had come in third place in the polls leading up to the 2015 election, and there seemed to be an opportunity for populism to sweep up these Eurosceptic narratives, both within and outside of the Conservative Party. Populism in the wake of the Brexit referendum would reshape the landscape of the Conservative Party. Several interviewees argued in some way that the Brexit movement, at its core, "relied on the idea of Britain as a global superpower," as one interviewee described it. There was a sentiment amongst many interviewees that a large number of the Conservative Party's membership "yearned for past glory" and saw it as "shameful" that a country with such "economic and global clout" is unable able to steer the welfare of its people and its businesses "on its own."

To a large extent, this sentiment of exceptionalism carried into the 2019 elections, where interviewees identified the "Get Brexit Done" slogan as a sign of an ascendant Britain. Indeed, the 2019 elections exemplified "the differences between the Conservatives and Labour parties." Boris Johnson's electoral campaign highlighted the strength of a fully independent Britain, while traditional Northern working class voters interpreted Labour's mixed Brexit message as evidence that the "Labour Party did not view Britain as a superpower" and that it "still wanted to rely on the European Union." Many interviewees identified the Johnson administration's coronavirus-era spending increases not just as an effort to head off a recession, but as an attempt to show the public that Britain can independently handle such a crisis without supranationalism. The government seems "acutely aware" of how Cameron's unpopular austerity policies had helped the Leave campaign succeed ${ }^{67}$ and now seems ideologically determined to increase the government's role in the domestic economy and prove that "Britain can go it alone."

[67] Thiemo Fetzer, “Did Austerity Cause Brexit?," American Economic Review 109.11 (2019): 3849-86, https://doi.org/10.1257/aer.20181164 


\section{Immigration}

Interviewees said that there is "no doubt" that anti-immigration rhetoric from UKIP and Nigel Farage during the Brexit referendum campaign "made it acceptable to talk about people 'flooding in' to the United Kingdom." Every interviewee that I spoke with was disdainful of this type of rhetoric, possibly due to a common socioeconomic background that has exposed them to metropolitan multiculturalism. Most were quick to observe that neither the Remain or Leave campaign sought to center immigration in their campaigns-only Nigel Farage's UKIP and other far-right groups "made it an issue." ${ }^{68}$ I was also told that while the Leave campaign was able to make its economic arguments by "outsourcing harsh, simple, and emotional rhetoric" to Farage, the Remain campaign had to fight on two fronts: economic and immigration-based.

Those who discussed immigration always identified Northern England as an area where negative attitudes towards immigration are more common. After the Treaty of Maastricht established free movement of people, there was a movement of nationals from Eastern European countries into the United Kingdom. Despite the fact that these immigrants typically lived closer to London, interviewees described a broad English sentiment that these immigrants were taking jobs or were being favored by "Etonian elites" over building up the "forgotten North." It is notable that anti-immigration voters tend to call for, and latch onto, political voices protestingthe free movement of people, such as UKIP's Nigel Farage. ${ }^{69}$ Amongst interviewees, views on immigration tended to correlate heavily with their preference for either Remaining or Leaving in the European Union. All described Priti Patel, current Secretary of State for the Home Department, as a pivotal Johnson government appointee who has signaled to those who supported Brexit that hardline immigration was on the agenda. One pro-Brexit interviewee described Priti Patel as "the heartthrob of all small-c conservative young men who want to see restricted immigration." Indeed, Boris Johnson's post-2019

[68] "EU Referendum: Nigel Farage Tells Leave Campaigners to Focus on Migration," BBC News, April 29, 2016, https://www.bbc.com/news/uk-politics-11598879 [69] Ibid. government has moved towards the ideological right on immigration by moving to implement a points-based immigration system, hiring more police officers and border enforcers, and publicly denouncing illegal migration..$^{\circ}$

\section{A Feedback Loop: The Working Class and the Conservative Main-} stream Merge

In addition to nation-wide concerns over immigration, the issue of Brexit has fundamentally reshaped the views of the English working class. As the 2019 election shows, the Labour Party's traditional working class strongholds in the North of England-known aptly as the "Red Wall"-overwhelmingly turned, constituency by constituency, in favor of the Conservative Party.1 The Conservative landslide, and large resultant majority, demonstrates that a political realignment has occurred in the United Kingdom: the Labour Party is now much more urban, while the Conservative Party has grown its majority by forging deep local ties in rural working class constituencies. These ties, forged through rhetoric pertaining to sovereignty and immigration, created a right-wing wave of populism that pulled the working class into the Conservative Party. One dejected staffer told me that the Conservatives have "expanded their base remarkably by cutting out people" like him-that is to say, he felt that Cameronites like himself no longer saw their beliefs represented in the Party's rhetoric or policies.

While some of this shift surely came from a desire to see Brexit through, interviews revealed a populism that changed both the electorate and the Conservative Party. Between the Brexit referendum campaign and the present day, both the voters and politicians have created a feedback loop that has reinforced this political realignment: the working class and the Conservative Party mutually reckoned each others' grievances, established alignment, and both drifted from the status quo libertarian ideol-

[70] Jessica Elgot, "Boris Johnson Vows Push on Immigration Points System," The Guardian, June 26, 2019, http://www.theguardian.com/politics/2019/jun/27/boris-johnson-vows-push-on-immigration-points-system

[71] "General Election 2019: How Labour's 'Red Wall' Turned Blue," BBC News, December 13, 2019, https://www.bbc.com/news/election-2019-50771014 
ogy and most city-based small-c conservatives. Oesch provides a robust framework with which to understand this political realignment. As he argues, "the working class has become the core clientele of right-wing populist parties in Western Europe" not just as a result of economic and welfare woes, but more importantly because of political discontent and the ideology of "cultural protectionism." ${ }^{72}$ When the working class simultaneously becomes disaffected with a country's democratic elites and fearful of the loss of an "exclusive form of community" to outsiders, they will turn towards right-wing populist parties. ${ }^{73}$ This paper considers this to be the core mechanism of the feedback loop.

This theory seems to hold especially true in the British case. Conservative interviewees used words such as "Etonian," "Oxbridge," and "London-centric" to describe not just the make-up of British politics, but also the make-up of their own Party in Parliament. Whether originally Remainers or Leavers, all expressed dissatisfaction with the degree to which the Conservative Party had, for a long time, appeared not to represent the country's working class. In this way, a politician like David Cameron failed to appeal to the working class, who were most exposed to 2010 fiscal cuts and disaffected with elites, and therefore more likely to support the Leave campaign. ${ }^{74}$ Instead, the Conservative Party lost votes to UKIP, the third largest party in the 2015 general election. According to interviewees, UKIP possessed a broadly right-wing populist agenda that was attractive to voters on both of Oesch's metrics: it positioned itself as an "alternative to elites" and as a "protector of the Englishman." In response, the Conservative Party co-opted these demand-side calls for populism and called for the Brexit referendum. ${ }^{75}$ My interviewees

[72] Daniel Oesch, "Explaining Workers' Support for Right-Wing Populist Parties in Western Europe: Evidence from Austria, Belgium, France, Norway, and Switzerland," International Political Science Review 29.3 (2008): 349, https://doi. org/10.1177/0192512107088390

[73] Oesch, "Explaining Workers' Support for Right-Wing Populist Parties in Western Europe: Evidence from Austria, Belgium, France, Norway, and Switzerland," 369.

[74] Colantone and Piero Stanig, "The Surge of Economic Nationalism in Western Europe," 142.

[75] Sara B. Hobolt, “The Brexit Vote: A Divided Nation, a Divided Continent," Journal of European Public Policy 23, no. 9 (October 20, 2016): 1259-77, https://doi.org/10.1080/ attributed this populism to Theresa May's failure in the 2017 general election. They said that, to voters, Theresa May represented "more of the same": traditional Etonian power in Parliament that would "embrace immigration and Europe" in spite of the referendum. However, Boris Johnson had a "clever" understanding of voter demand and was able to use his power as an influential agenda-setter to spread his own brand of nationalism and lead the party into the 2019 general elections with the slogan "Get Brexit Done."

\section{The New Conservative Party and the Libertarian- Authoritarian Dichotomy}

\section{The 2019 Election Sparked a Political Realignment}

Interviewees were careful to note that, under Theresa May, many Conservative MPs saw the process of leaving the EU as a "damage limitation exercise"; the goal of these individuals was to ensure as "soft" a Brexit as possible. After the three failures of Parliament to pass Theresa May's EU Withdrawal Agreements, the increasing frustration on the Conservative right, in the tabloids, and among the electorate, led these political figures to be labeled "Remoaners"-a term referring to all MPs, but especially Conservatives who voted to remain and were "obstructing Brexit" in the House of Commons. Conservative Remoaners were described as "working with Labour" and going against their own party. According to interviewees, the Remoaner label was fueled by exhaustion with the Brexit proceedings. Politicians and voters alike simply wanted Brexit to be out of their news cycle and viewed attempts to "water down Brexit" as the undemocratic actions of Etonian elites who "thought they knew better than the majority of voters." When none of these grievances were resolved on their own under Boris Johnson's leadership, he stripped the twenty-one Conservative MPs of the whip as punishment for betraying the new party line. ${ }^{7}$ Those who did not have their whip restored were essentially forced out of their seats by new candidates who created a "much more pro-Brexit Conservative Party in Parliament."

13501763.2016.1225785.

[76] "Brexit Showdown: Who Were Tory Rebels Who Defied Boris Johnson?," BBC News, September 5, 2019, https://www.bbc.com/news/uk-politics-49563357 
While Johnson withheld his stance on policy issues throughout the 2019 campaign to "play his cards close to his chest so that no one could know what he believed," he made an "end to the Remoaners" a priority through his "Get Brexit Done" slogan. The slogan was quite popular within swing constituencies in the North, whose Labour voters had warmed to the idea of Brexit or had become frustrated with the Labour Party's "lack of message" on Brexit.7 Moreover, Johnson's Conservative associations in these constituencies were sure to nominate "local people who understood" both the Brexit message and the struggles of the working class. These new local representatives were "small-c conservatives" and highly pro-Brexit. The interviewees described Labour candidates as "rudderless" on the issue of Brexit; Labour leaders promised a return to traditional values that "the Labour Party could not provide because they were enamored with the cities and cosmopolitan-minded voters."

This new Conservative bloc that entered the House of Commons in the wake of the 2019 election, along with the small-c conservative Members of Parliament who were already there, dominated the Conservative Party in Parliament. This new intake knew, and knows, that its electoral prospects are contingent upon its ability to deliver both Brexit as well as prosperity for the working class. As such, the ideological makeup of Conservative MPs was pulled away from the socially liberal, yet economically austere, wing of the party that had dominated the Party in Parliament for so long. In its place stands a set of Conservative MPs that is more socially traditional, but that has sought to recapture the pre-Thatcher concept of paternalistic "One-Nation Conservatism" supporting expanded government programs to bolster citizens' well-being.

\section{Libertarians Versus Authoritarians}

This ideological shift in the Conservative Party was exemplified by a changing of the guard, so to speak, within the party's leadership. Figures

[77] Heather Stewart, “Johnson's 'Get Brexit Done’ Strategy Resonates with Marginal Focus Groups," December 6, 2019, The Guardian, http://www.theguardian.com/ politics/2019/dec/06/johnsons-get-brexit-done-strategy-resonates-with-marginal-focus-groups. like David Cameron and Dominic Grieve-socially liberal, fiscal conservatives who supported Remain-were replaced by people like Dominic Cumming and Priti Patel-more "traditionalist" voices who want Britain to "rediscover itself as a nation that provides for its own people." This replacement was noted by every single interviewee from every single background. Without passing a moral judgment, most described this divide using these exact terms: "libertarianism" versus "authoritarianism" within the Conservative Party. I was told that, while these two factions have existed in some shape or form for decades, if not centuries (dating back to the divide between Whigs and Tories), the authoritarians have prevailed in today's Conservative Party since Brexit. By "libertarian," interviewees referred to an increasingly small role for the British state in markets alongside an increasingly socially liberal support for higher immigration, the LGBTQ+ community, and racial justice. By "authoritarian," they were referring to an increasing willingness to intervene in the economy as well as to support more socially conservative policies that limit libertarian causes, such as increasing the number of police officers, implementing a points-based immigration system, and "making transgender issues an ideological fault line." These words should not be construed as morally loaded; only as indicating the proclivity for Conservative Party politicians and voters to support a larger authority role for the state in economic or social affairs.

In this "Libertarian-Authoritarian dichotomy," interviewees identified the Conservative Party's libertarian wing as a "longstanding" ideological establishment since Margaret Thatcher realigned British politics along neoliberal lines. Placing new limitations on the welfare state and lowering taxes became accepted as necessary steps to "allow the private sector and the individual to thrive." While Euroscepticism did existincluding, to a small extent, from Thatcher herself-it was mostly cast to the sides of the political mainstream by the influence of the Tory Reform Group (TRG) and the Conservative Group for Europe (CGE), which were described to me by interviewees as "instrumental in promoting pro-European Union views and social progress." The TRG was described to me as particularly influential, and as being crucial to the maintenance and preservation of the National Health Service as well 
as to social policy victories for British progressives, such as the Conservative Party-led legalization of gay marriage. Indeed, most Conservative Party Leaders in the post-Thatcher years-John Major, Michael Howard, David Cameron, and Theresa May-have either been directly affiliated with the TRG or have actively praised its brand of socially liberal, one-nation conservatism. ${ }^{78}$ On the other hand, the ascendant authoritarian branch of the Conservative Party sought to "reclaim traditional values" and legitimize itself as the coalition of the working class that could deliver one-nation conservatism. Proponents of this type of conservatism heavily emphasize "sovereignty as a reason for a strong government role in the economy." One interviewee shared that " $t]$ he United Kingdom now has something to prove, which is that the national government can provide for its own people better than Brussels could." This sentiment was shared by the other interviewees who were supportive of Leaving the European Union. For instance, while Cameron had spoken about the Conservative Party's "Northern Powerhouse" policies that would reignite the economies of the North of England, these working class constituencies felt that change had not come and that Cameron's government had instead "focused on the cosmopolitan interests of London and Brussels."

Interviewees also found that the Johnson administration's message of "Leveling Up the North" has already been successful in instituting a points-based immigration system, ending free movement from Europe, and passing economic stimulus in the face of the coronavirus pandemic (rather than austerity). Immigration, of course, was at the top of voters' minds ahead of the referendum. ${ }^{79}$ Interviewees often cited the Europe-

[78] “About Us," website, Tory Reform Group, https://www.trg.org.uk/about-us/\#patrons;"Letter from Theresa May to the TRG Membership," Tory Reform Group, https://www.trg.org.uk/wp-content/uploads/2016/07/TRG-and-the-Leadership-of-ourParty.pdf; "2019 Feb. 20 Statement from the Tory Reform Group," Tory Reform Group, February 20th, 2019, https://www.trg.org.uk/statement-from-the-tory-reform-group/

[79] Scott Blinder and William Allen, "UK Public Opinion Toward Immigration: Overall Attitudes and Level Of Concern," report, Migration Observatory, University of Oxford (2016), https://migrationobservatory.ox.ac.uk/wp-content/uploads/2016/04/Briefing-Public_Opinion_Immigration_Attitudes_Concern.pdf an Research Group (ERG) as an organization that pushed these ideological values within the party apparatus. Political figures and Leave Campaigners such as Priti Patel, Michael Gove, and Steve Baker had described the pre-Johnson Conservative administration's push for globalization and European integration as a failure to protect the "core people of England." Implicit in the 2019 election was the idea that these "Remoaners," who claimed to espouse the ideals of one-nation conservatism, had actually forgotten about the people that the government was meant to serve. To the interviewees, a bipartisan Major/Blair/Cameron policy consensus had emerged in the cities, and austerity and European integration had "hung the North of England out to dry." In this way, this authoritarian branch was able to claim one-nation conservatism for themselves by grouping libertarian Conservatives and the Labour Party as one and the same: serving establishment, Etonian, cosmopolitan elites at the expense of "the silent majority."

At the same time, social issues such as increasing police funding have become priorities within the Conservative Party. As such, the left-right spectrum that the Conservative Party had traditionally possessed has been supplanted. Rather than Conservative divisions along social or economic issues, the Party's political spectrum is now defined by the degree to which one supports policies that ostensibly "protect" the cultural traditions or economic power of the nation. This authoritarian wing of the party has created a disaffected center/center-right group of Conservative libertarians who "tend to be middle class cosmopolitans" falling into one of two camps: They have either begrudgingly accepted what the right/far-right touts as the "democratic argument" in favor of honoring what the new Conservative constituency wants, or "they have left the party." Those who do not agree with the new majority's decisionssuch as Boris Johnson's EU Withdrawal Bill which unites Northern Ireland and Britain customs across the Irish Sea and undermines the "traditionally Unionist nature of the Conservative Party"-have now "lost a place in mainstream British politics" and have been replaced by "a much larger, much noisier electorate that is less middle class and more working class." 


\section{View of the Labour Party Today}

Interviewees also shared their views on the Labour Party in the wake of the 2019 elections, and their differing views based on their self-identification as either libertarian or authoritarian. Those who considered themselves to be more pro-Remain or more libertarian tended to see the appointment of Keir Starmer as a positive step for the Labour Party "so that it can be a party that holds Conservatives to account." These interviewees saw a robust opposition that the public could support as "crucial to British democracy." They also viewed the Labour Party as a more legitimate contender in future elections due to "more competent leadership that can win back the North by the end of the 2020 s if Boris Johnson falters." Those who tended to be more pro-Leave, or who belonged to the office of an MP that had been newly elected from the North in 2019, saw things much differently. To these interviewees, Starmer represented a "far-left Corbyn lieutenant" who "tried to overturn democracy with a second referendum." Dismayed, they told me that Labour was "opposed to absolutely everything," though they did note that the Labour Party had broadly supported the Johnson government on policies to mitigate the coronavirus pandemic. They said that, in the North, voters view the Labour Party as far-left and "anti-British," asserting that Labour had become "too city-based" and "no longer [had] a love of country, and hate traditions." The stark difference in interviewees' opinions about Labour opposition between those who subscribed to the libertarian versus authoritarian branches of the Conservative Party was indicative of the party's changing nature. They saw "culture issues in the United States" as having arrived on British soil and pushing Labour and "professional, white-collar Conservatives towards extremes." "When America sneezes," one senior staffer from a freshman MP's office told me, "Britain catches a cold." Only these new Conservatives, several believed, could "reject the status quo and restore Britain" without being hampered by globalization or by the European Union.

\section{A "Do What It Takes to Win" Mentality}

Regardless of whether or not an interviewee had personally been pro-Remain or pro-Leave, virtually all of them repeated some version of the following line: "The Conservative Party will do whatever it can to win, and that is why it is the most successful political party [at winning elections] in the world." As such, in the face of fracture during the defeats of Theresa May's Government, the Conservative Party leaned on what it had learned in the 2019 election: that "Get Brexit Done" appeared to be a winning slogan, that the Labour Party could be portrayed as weak and as lacking a decisive message, and that libertarian "Remoaners" who were not on board with any aspect of the Johnson Government's agenda could be criticized as stemming the tides of democracy. This "do what it takes to win" mentality appears to be a mechanism of rapid change within the Conservative Party. Interviewees and mass media depicted Boris Johnson as the embodiment of this "do what it takes to win" approach. It was abundantly clear to both Remainers and Leavers that, in 2016, "Johnson sniffed the chance to become prime minister, and-in Union jargon-decided at the last minute to back the [Brexit] motion." ${ }^{80}$

Despite "personally being a libertarian who represented social liberal ideas as the Mayor of London," Boris Johnson has reinvented himself entirely around the issue of Brexit. As Prime Minister, he has promised to "take the European Union to task" in his Withdrawal deal, and has forwarded a No-Deal Brexit as an alternative choice that "Britain is strong enough to get behind if it must." He has become an advocate for expanded governmental involvement in welfare and in local economies, and has been "the first Conservative Prime Minister in a long time to veto local Councilors" ordinances." Additionally, he has embraced his party's willingness to intervene on social issues: He has named Priti Patel his Home Secretary, who is reshaping immigration by imposing points-based limits that favor high-skilled labor from Commonwealth member-states in place of free movement of labor to and from Europe. Similarly, the Government is now hiring new immigration and police officers and has promised the British people that the United Kingdom is strong enough to grow on its own without any trade deal with the

[80] Simon Kuper, "How Oxford University Shaped Brexit-and Britain's Next Prime Minister," Financial Times, September 18, 2019, https://www.ft.com/content/85fc694c9222-11e9-b7ea-60e35ef678d2 
European Union. This approach appears to have been successful for the Johnson Government. Even though "some of the voters in the center have been left without a party," the new Conservative "voters who granted UKIP the third-largest vote share in the 2015 elections" re-emerged to "[deliver] the Conservative Party an unquestionable right-wing mandate." As such, voters who had "[fled the center]" as Hobolt and Tilley say happened across Europe in the wake of the Great Recession due to fears over "EU integration, austerity, and immigration" have fully realigned the Conservative electorate away from the libertarian wing of the party through their support of UKIP, and then of Boris Johnson. ${ }^{81}$

\section{Conclusion and Future Research}

Contemporary populism and nationalism have never been more salient than they are today, both within scholarship and society at-large. Within the European context, no populist movement has seen greater or more consequential success than the Brexit movement, which has successfully shepherded the United Kingdom out of the European Union. These populist ideas have co-opted the mainstream British Conservative Party in a way that has pushed its policy and rhetoric further to the political right.

In this study, I sought to understand Brexit within the context of this surge of far-right populism, which continues to persist in the United Kingdom and Europe at-large. To learn both why the Conservative Party has changed so markedly in response to the ongoing Brexit negotiations as well as what realities explain the Party's rhetorical and general policy changes and factional shifts, I conducted interviews with Conservative Party actors. I then analyzed these interviews according to the "Third Way" school of thought, which has been especially well-articulated by Vines and Marsh, who argue for a recognition of the relationship between politicians and citizens rather than a focus on either of these

[81] Sara B. Hobolt, and James Tilley, "Fleeing the Centre: The Rise of Challenger Parties in the Aftermath of the Euro Crisis," West European Politics 39, no. 5 (September 2, 2016): 971, https://doi.org/10.1080/01402382.2016.1181871. groups. ${ }^{82}$ Overall, this study found the key themes of contemporary British populism to be Euroscepticism, sovereignty, and immigration. It also found three mechanisms mobilizing populist discourse within the Conservative Party and the voters: a feedback loop between the English working class and the Party apparatus, an active dispute between libertarians and authoritarians in the Party, and a Parliamentary "do what it takes to win" mentality allowed the Conservative Party to re-establish party unity around the new ideological consensus.

There has been a "decoupling of political authorities and citizens" leading up to Brexit, a decoupling that continued between Conservative Party political authorities and its voters until the 2019 election. ${ }^{83}$ Local activism for the Brexit vote by UKIP and the Leave Campaign promised an interactive democracy that could do what the status quo could not. ${ }^{84}$ Reciprocally, the Conservative Party has been realigned by these voters, as they elected locally-raised Parliamentary candidates to "deliver Brexit themselves" and succeed where the libertarians had failed. ${ }^{85}$ This decoupling of huge swaths of voters from their typical political loyalties, such as the Labour Party in the North or a more "politically moderate" sect of the Conservative Party, is the result of a feedback loop between the working class ("demanders" of populism) and Conservative politicians ("suppliers" of populism) from the authoritarian wing of the party. ${ }^{86}$ Each propelled ideas that major parties in the United Kingdom had rejected for decades into the political mainstream: an isolationist, "goit-alone" approach towards Europe, a shift towards pre-Thatcherite economics, and a desire to "look inward, rather than outward."

A perfect storm of events sparked by the British referendum contrib-

[82] Vines and Marsh, "Anti-Politics: Beyond Supply-Side versus Demand-Side Explanations," 446-447.

[83] Ibid., 438 .

[84] Henrik P. Bang, "Yes We Can': Identity Politics and Project Politics for a Late-Modern World," Urban Research \& Practice 2.2 (2009): 117, https://doi. org/10.1080/17535060902979022

[85] Ibid., 117.

[86] Vines and Marsh, "Anti-Politics: Beyond Supply-Side versus Demand-Side Explanations," 450. 
uted to this political realignment: The Great Recession, agenda-setting by UKIP and Nigel Farage, the Eurozone crisis, austerity policies, and the systemic move towards policies that support the British middle- and upper-classes by the Conservative and Labour Parties for decades. This realignment cannot be attributed to supplied populism or demanded populism, but rather must be attributed to a highly "interactive and iterative" process of communication between the Conservative Party and a shifting, restless base of disaffected voters ${ }^{87}$ As such, while scholars such as Mete, de Búrca, and Mondon provide valuable contributions to the study of either supplied or demanded populism, the British case of populism indicates that we should view supplied and demanded populism as a "duality," not a "dualism."

The supply-demand conversation regarding populism began in the wake of the 2015 elections, during which the UKIP established itself as a major power by tapping into latent disaffection and anti-political ideas and formally proposed a Brexit referendum. Next, the 2016 Brexit referendum itself demonstrated voter demand for populism. Another inflection point after the referendum was the failure of the libertarian wing of the Conservative Party to "win the day in the Commons," after which voters became more disaffected with traditional politics. Finally, the 2019 elections solidified the political realignment and crystallized disdain for "Remoaners," austerity, globalization, and cosmopolitanism. This disdain now exists both within the Conservative Party in Parliament and within the party's base. This has been clearly communicated by the deselection of libertarian members who were labeled as "disloyal Remoaners," and by the new intake of Northern English MPs who are more authoritarian in their policy outlook and are "not Etonians, and represent the people who elected them." Today, this shift means that voters expect their Conservative Party to be more socially right wing (on issues such as immigration, policing, and gender identity) and more economically

\section{[87] Ibid., 436.}

[88] Ibid., 450; see also Mete, "Four Types of Anti-Politics: Insights from the Italian Case”; de Búrca, "How British Was the Brexit Vote?"; Mondon, “Populism, the 'People' and the Illusion of Democracy." paternalist (to be more "sovereign/independent" and "powerful/capable of providing"). So far, the Johnson government seems to be delivering these new types of policies, as is exemplified by heavy government spending in the face of the coronavirus pandemic. ${ }^{89}$

Future researchers can expand on these findings in four main ways. First, researchers should continue to analyze the state of British populism in the years post-Withdrawal and post-COVID-19. The degree to which the Northern working class stays with the Conservative Party, as well as the degree to which libertarian-leaning Conservative MPs return to the cabinet in a post-deal cabinet shake-up, will determine how strong the bonds are between the new Conservative electorate and the Johnson government's appeal to the right. Second, future papers can employ the "Third Way" approach to other cross-national examples, such as to the French National Rally, populism across the political spectrum in Germany, or the rise of Jair Bolsonaro in Brazil and his continued grip on populist support. Many scholars have studied changes within political parties, especially of those in the United States, in terms of party shifts, populism, and ideology. Conducting similar interpretivist studies in countries other than the UK-for example, the post-Donald Trump Republican Party-may yield interesting results, patterns, and perspectives on mechanisms of action for intraparty changes.

Third, scholars should examine the Conservative Party's "libertarian-authoritarian" dichotomy described by this paper"s interviewees, both with respect to the Conservative Party and with respect to other political parties around the world. For instance, future studies might ask whether this dichotomy is useful in understanding contemporary or historical political realignments, with or without respect to populism. Finally, this paper holds that disaffected voters and politicians will quickly establish a feedback loop that advocates against globalization, supranational unions, and socioeconomic elites in the education system.

[89] Deborah Mattinson, "Red Wall Voters Are Sticking with Boris Johnson (For Now)," September 6, 2020, The Guardian, http://www.theguardian.com/politics/2020/sep/06/ red-wall-voters-are-sticking-with-boris-johnson-for-now 
As such, a fourth area that both policymakers and researchers should continue to explore is the impact of increasing income inequality and urban economic prosperity as a result of globalism. Policymakers and scholars should pay special attention to the impact of supranationalism on the collective identity and psyche of rural populations. For instance, scholars should test whether or not successful government measures to redistribute the earnings of globalization's "winners" to globalization's "losers" are successful at breaking this anti-political feedback loop and restoring the honor and self-image within rural communities facing stagnant wages, high unemployment, and underdeveloped infrastructure. Researchers should also examine the effect of mainstream parties' austerity policies on third-party populist rhetoric.

\section{APPENDIX A: CODED THEMES AND CATEGORIES}

Populism

*corruption; ${ }^{* * *}$ economic anxiety; ${ }^{* *}$ globalization; ${ }^{* * \text { England/ }}$ Wales; ${ }^{\star}$ English Midlands; ${ }^{\star \star \star}$ Etonianism/Oxbridge ${ }^{\star * *}$ Euroscepticism; ${ }^{\star \star}$ Federal Europe; ${ }^{* *}$ feedback loop; ${ }^{* * *}$ immigration; ${ }^{* *}$ nationalism; ${ }^{* *}$ Northern England ${ }^{* * *}$ sovereignty; ${ }^{* * *}$ working-class ${ }^{\star *}$ Chequers plan; ${ }^{* \star}$ European Research Group; ${ }^{\star * \star}$ foreign labor; ${ }^{* * *}$ healthcare/NHS; ${ }^{* *}$ Irish backstop; ${ }^{* * *}$ Labour Party (and failures of); ${ }^{\star * \star}$ Leavers; ${ }^{* \star}$ nasty/messy politics; ${ }^{* \star *}$ Nigel

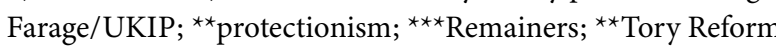
Group; ${ }^{* *}$ withdrawal agreement(s); ${ }^{*}$ young vs. old Leaver

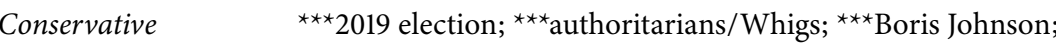
Party $\quad{ }^{* * *}$ David Cameron; ${ }^{* * *}$ "do what it takes to win"; ${ }^{*}$ John Major; ${ }^{* * *}$ libertarians/Tories; ${ }^{* *}$ Margaret Thatcher; ${ }^{* *}$ messaging; ${ }^{* * *}$ new composition; ${ }^{* * *}$ new electorate; ${ }^{* * *}$ new intake;

${ }^{* *}$ one-nation conservatism; ${ }^{* *}$ Red Wall; ${ }^{* *}$ Theresa May

${ }^{\star}$ British Commonwealth; ${ }^{\star \star}$ devolution; ${ }^{\star \star}$ Dominic Cummings; ${ }^{\star}$ Dominic Grieve; ${ }^{\star \star}$ Jeremy Corbyn; ${ }^{\star \star}$ John Bercow ${ }^{\star}$ Keir Starmer; ${ }^{\star \star}$ Northern Ireland; ${ }^{* \star \star}$ Priti Patel; ${ }^{\star *}$ Scottish independence; ${ }^{\star *}$ social media; ${ }^{\star}$ Tony Blair

${ }^{\star}$ Rarely Mentioned

${ }^{\star *}$ Commonly Mentioned

${ }^{* * * A l m o s t}$ Always Mentioned

\section{REFERENCES}

Bang, Henrik P. "'Yes We Can': Identity Politics and Project Politics for a Late-Modern World." Urban Research \& Practice 2.2 (2009): 117-37. https://doi. org/10.1080/17535060902979022

"Brexit Showdown: Who Were Tory Rebels Who Defied Boris Johnson?" BBC News, September 5, 2019. https://www.bbc.com/news/uk-politics-49563357

Bekhuis, Hidde, Roza Meuleman, and Marcel Lubbers. "Globalization and Support for National Cultural Protectionism from a Cross-National Perspective." European Sociological Review 29.5 (2013): 1040-1052. https://doi.org/10.1093/esr/jcs080

Blinder, Scott, and William Allen, "UK Public Opinion Toward Immigration: Overall Attitudes and Level Of Concern," report, Migration Observatory, University of Oxford (2016), https://migrationobservatory.ox.ac.uk/wp-content/uploads/2016/04/Briefing-Public_Opinion_Immigration_Attitudes_Concern.pdf

Búrca, Gráinne de. "How British Was the Brexit Vote?" In Brexit and Beyond: Rethinking the Futures of Europe. Edited by Benjamin Martill and Uta Staiger. London, GBR: University College London Press, 2018: 46-52. https://doi.org/10.2307/j.ctt20krxf8.10

Colantone, Italo, and Piero Stanig. "The Surge of Economic Nationalism in Western Europe." Journal of Economic Perspectives 33.4 (2019): 128-51. https://doi.org/10.1257/ jep.33.4.128

Elgot, Jessica. "Boris Johnson Vows Push on Immigration Points System." The Guardian, June 26, 2019. http://www.theguardian.com/politics/2019/jun/27/boris-johnson-vowspush-on-immigration-points-system

"EU Referendum: Nigel Farage Tells Leave Campaigners to Focus on Migration." BBC News, April 29, 2016. https://www.bbc.com/news/uk-politics-11598879

"Euro Moments: Thatcher Says 'No, No, No' to Europe." BBC News, May 14, 2014 https://www.bbc.com/news/av/uk-politics-27053536

"Eurostat Economic Indicators." Report. Eurostat, European Union. https://ec.europa. eu/eurostat/cache/infographs/economy/desktop/index.html

Fetzer, Thiemo. "Did Austerity Cause Brexit?" American Economic Review 109.11 (2019): 3849-86. https://doi.org/10.1257/aer.20181164

Flamini, Roland. “The UK Independence Party: Euroskeptics Rattle Cameron.” World Affairs 176.2 (2013): 35-41. https://www.jstor.org/stable/43554778

"General Election 2019: How Labour's 'Red Wall' Turned Blue." BBC News, December 13, 2019. https://www.bbc.com/news/election-2019-50771014 
Golder, Matt. "Far Right Parties in Europe." Annual Review of Political Science 19.1, May 11, 2016: 477-97. https://doi.org/10.1146/annurev-polisci-042814-012441

Halikiopoulou, Daphne, and Sofia Vasilopoulou. "Support for the Far Right in the 2014 European Parliament Elections: A Comparative Perspective.” Political Quarterly 85.3 (2014): 285-88. https://doi.org/10.1111/1467-923X.12102

- - , and Tim Vlandas. "What Is New and What Is Nationalist about Europe's New Nationalism? Explaining the Rise of the Far Right in Europe." Nations and Nationalism 25.2 (2019): 409-34. https://doi.org/10.1111/nana.12515

Hearn, Jonathan. "Vox Populi: Nationalism, Globalization And The Balance Of Power In The Making Of Brexit." In Brexit: Sociological Responses. Edited by William Outhwaite, 19-30. London, GBR: Anthem Press, 2017. https://www.jstor.org/stable/j.cttlk$\mathrm{ft} 8 \mathrm{~cd} .5$

Hobolt, Sara B., and James Tilley. "Fleeing the Centre: The Rise of Challenger Parties in the Aftermath of the Euro Crisis." West European Politics 39.5 (2016): 971-91. https://doi. org $/ 10.1080 / 01402382.2016 .1181871$

- - - “The Brexit Vote: A Divided Nation, a Divided Continent." Journal of European Public Policy 23.9 (2016): 1259-77. https://doi.org/10.1080/13501763.2016.1225785

- - , and Catherine de Vries. "Turning against the Union? The Impact of the Crisis on the Eurosceptic Vote in the 2014 European Parliament Elections." Electoral Studies 44 (2016): 504-14. https://doi.org/10.1016/j.electstud.2016.05.006

"How Long Can Labour's Eurosceptic Leader Keep Europhile Members Happy?" The Economist, January 10, 2019. https://www.economist.com/britain/2019/01/10/ how-long-can-labours-eurosceptic-leader-keep-europhile-members-happy.

Juncker, Jean-Claude. "President Juncker Delivers State of the Union Address 2017." European Commission. September 13, 2017. https://ec.europa.eu/commission/presscorner/ detail/en/SPEECH_17_3165

Karakas, Leyla D., and Devashish Mitra. "Inequality, Redistribution and the Rise of Outsider Candidates." Games and Economic Behavior 124 (2020): 1-16, https://doi. org/10.1016/j.geb.2020.07.012

Kuper, Simon. "How Oxford University Shaped Brexit-and Britain's Next Prime Minister." Financial Times, September 18, 2019. https://www.ft.com/content/85fc694c-9222-11e9-b7ea60e35ef678d2.

Lubbers, Marcel, and Peer Scheepers. "French Front National Voting: A Micro and Macro Perspective." Ethnic and Racial Studies 25.1 (2002): 120-49. https://doi. org/10.1080/01419870120112085
Mair, Peter. "Ruling the Void: The Hollowing of Western Democracy." New Left Review 42 (2006): 25-51. http://hdl.handle.net/1814/6418

Mattinson, Deborah. "Red Wall Voters Are Sticking with Boris Johnson (For Now)" September 6, 2020. The Guardian. http://www.theguardian.com/politics/2020/sep/06/ red-wall-voters-are-sticking-with-boris-johnson-for-now

Mete, Vittorio. "Four Types of Anti-Politics: Insights from the Italian Case." Modern Italy 15.1 (2010): 37-61. https://doi.org/10.1080/13532940903477872

Mondon, Aurelien. "Populism, the 'People' and the Illusion of Democracy-The Front National and UKIP in a Comparative Context.” French Politics 13.2 (2015): 141-56. http://dx.doi.org/10.1057/fp.2015.6

Mounk, Yascha. "Pitchfork Politics: The Populist Threat to Liberal Democracy." Foreign Affairs 93.5 (2014): 27-36. https://www.jstor.org/stable/24483300

Mudde, Cas. "The Populist Radical Right: A Pathological Normalcy." West European Politics 33.6 (2010): 1167-86. https://doi.org/10.1080/01402382.2010.508901

Mukand, Sharun, and Dani Rodrik. "The Political Economy of Liberal Democracy." CESifo Working Paper Series 6433 (2017). https://papers.ssrn.com/sol3/papers.cfm?abstract_id=2973082

Oesch, Daniel. “Explaining Workers' Support for Right-Wing Populist Parties in Western Europe: Evidence from Austria, Belgium, France, Norway, and Switzerland." International Political Science Review 29.3 (2008): 349-73. https://doi.org/10.1177/0192512107088390

Oliver, Tim. “Goodbye Britannia? The International Implications Of Britain's Vote To Leave The EU." Geopolitics, History, and International Relations 8.2 (2016): 214-33. https://doi.org/10.22381/GHIR82201610

Polyakova, Alina, and Anton Shekhovtsov. “On the Rise: Europe's Fringe Right.” World Affairs 179.1 (2016): 70-80. https://doi.org/10.1177/0043820016662746

Post, Jerrold. Leaders and Their Followers in a Dangerous World (Ithaca, NY: Cornell University Press, 2004).

Rodrik, Dani. "Populism and the Economics of Globalization." Journal of International Business Policy, 2018. https://doi.org/10.1057/s42214-018-0001-4

Scheuch, Erwin K., and Hans D. Klingemann. "Theorie des Rechtsradikalismus in westlichen Industriegesellschaften." Hamburger Jahrbuch für Wirtschafts und Gesellschaftspolitik 12 (1967): 11-29. As cited in Mudde, Cas. "The Populist Radical Right: A Pathological Normalcy.” West European Politics 33.6 (2010): 1167-86. https://doi.org/10.1 080/01402382.2010.508901 
Sierakowski, Slawomir. "In Europe, the Only Choice Is Right or Far-Right." Foreign Policy Magazine. May 21, 2018. https://foreignpolicy.com/2018/05/21/in-europe-the-onlychoice-is-right-or-far-right/.

Startin, Nicholas. "Have We Reached a Tipping Point? The Mainstreaming of Euroscepticism in the UK." International Political Science Review / Revue Internationale de Science Politique 36.3 (2015): 311-23. https://doi.org/10.1177/0192512115574126

Stewart, Heather. "Johnson's 'Get Brexit Done' Strategy Resonates with Marginal Focus Groups.” December 6, 2019, The Guardian. http://www.theguardian.com/politics/2019/ $\mathrm{dec} / 06 /$ johnsons-get-brexit-done-strategy-resonates-with-marginal-focus-groups

"Thatcher and Her Tussles with Europe." BBC News, April 8, 2013. https://www.bbc. com/news/uk-politics-11598879

Thatcher, Margaret. "Speech to the College of Europe ('The Bruges Speech')." September 20, 1988.

“The Great Divide." The Economist. September 15, 2012. https://www.economist.com/ britain/2012/09/15/the-great-divide

"About Us." Website. Tory Reform Group. https://www.trg.org.uk/about-us/\#patrons

"Letter from Theresa May to the TRG Membership." Tory Reform Group. https://www. trg.org.uk/wp-content/uploads/2016/07/TRG-and-the-Leadership-of-our-Party.pdf

"2019 Feb. 20 Statement from the Tory Reform Group." Tory Reform Group. February 20th, 2019. https://www.trg.org.uk/statement-from-the-tory-reform-group/

Umbrasas, Karl. "Psychopolitics of the Current Nationalism." Journal of Strategic Security 10.4 (2017): 29-41. https://doi.org/10.5038/1944-0472.10.4.1616

Ünver, Hamid A. "Corrective Parties and Conveyor Coalitions: Explaining the Rise of Third Parties in European Politics.” Perceptions; Balgat 21.2 (2016): 1-28. https://search. proquest.com/docview/1892979630/abstract/973196B434C6423BPQ/1.

Van Spanje, Joost. "Parties beyond the Pale: Why Some Political Parties Are Ostracized by Their Competitors While Others Are Not." Comparative European Politics 8.3 (2010): 354-83. http://dx.doi.org/10.1057/cep.2009.2

Vasilopoulos, Pavlos, George E. Marcus, Nicholas A. Valentino, and Martial Foucault. "Fear, Anger, and Voting for the Far Right: Evidence From the November 13, 2015 Paris Terror Attacks." Political Psychology 40.4 (2019): 679-704. https://doi.org/10.1111/ pops. 12513

Vines, Emma, and David Marsh. "Anti-Politics: Beyond Supply-Side versus Demand-Side Explanations." British Politics 13.4 (2018): 433-53. https://doi.org/10.1057/ s41293-017-0053-9 